ORIGINAL ARTICLE / ARTIGO ORIGINAL

\title{
Predictors and geographic analysis of road traffic accidents in Leon, Nicaragua
}

\author{
Preditores e análise geográfica de acidentes de trânsito em León, Nicarálgua \\ Christian Toval-Ruiz' (D), Carlos Rojas-Roquel iD, Akram Hernández-Vásquez" (D)
}

ABSTRACT: Objective: To identify environmental factors present in areas with high density of road traffic accidents (RTA) in Leon, Nicaragua. Methods: The analysis included all accidents recorded by the Police Department in León City, from January to June 2017. All crashes were georeferenced, and data were collected from the environment elements within a perimeter of 20 meters from the site in which accidents occurred with a pre-tested data collection instrument. We specified a Poisson regression model to estimate incidence rate ratios (IRR) and $95 \%$ confidence intervals (CI) to determine environmental factors associated with the event incidence. For the identification areas with high, medium, and low occurrences of crashes, kernel density around points in which RTA occurred were estimated. Results: Out of 667 recorded crashes, $90 \%$ involved men aged $15-40$, and motorcycle accidents represented $60 \%$ of injuries or deaths. Environmental factors that were positively associated with RTA included good road conditions (adjusted IRR $=1.36,95 \%$ CI $1.13-1.63$ ) and the existence of bicycle lanes (adjusted IRR $=1.64,95 \%$ CI $1.29-2.10$ ). Environmental characteristics associated with higher speeds and heavier accidents can increase their incidence. Conclusion: We found that high-foot-traffic commercial or touristic centers are three areas with high density of crashes. Local authorities can use these findings to promote road safety measures in high-incidence areas in León City.

Keywords: Accidents, traffic. Epidemiology. Geographic Information Systems. Nicaragua.

'Centro de Investigación en Demografía y Salud, Facultad de Ciencias Médicas, Universidad Nacional Autónoma de Nicaragua León, Nicaragua.

"Universidad San Ignacio de Loyola, Vicerrectorado de Investigación, Centro de Excelencia en Investigaciones Económicas y Sociales en Salud - Lima, Peru.

Corresponding author: Christian Toval-Ruiz. Centro de Investigación en Demografía y Salud, Facultad de Ciencias Médicas, Universidad Nacional Autónoma de Nicaragua. La Merced Church 1/2 block West, 21000, León, Nicaragua. E-mail: chris0412toval@gmail.com Conflict of interests: nothing to declare - Financial support: none. 
RESUMO: Objetivo: Identificar os fatores ambientais presentes em áreas com alta densidade de acidentes de trânsito rodoviário (ATR) em León, Nicarágua. Métodos: Foram incluídos na análise todos os acidentes registrados pelo Departamento de Polícia da cidade de León de janeiro a junho de 2017. Georreferenciamos todos os acidentes e coletamos dados dos elementos ambientais em um perímetro de 20 metros do local até os acidentes ocorridos por meio de um instrumento de coleta de dados pré-testado. Foi especificado um modelo de regressão de Poisson para estimar as razões das taxas de incidência (TI) e intervalos de confiança de 95\% (IC95\%) para determinar os fatores ambientais associados à incidência do evento. Para identificar áreas com alta, média e baixa ocorrência de acidentes, estimamos a densidade do núcleo em torno dos pontos onde o ATR ocorreu. Resultados: Dos 667 acidentes registrados, $90 \%$ envolveram homens com idades entre 15 e 40 anos, e os acidentes de motocicleta representaram $60 \%$ dos ferimentos ou mortes. Os fatores ambientais que foram associados positivamente aos ATR incluíram boas condições da estrada (TI ajustada = 1,36; IC95\% 1,13 - 1,63) e a existência de ciclovias (TI ajustada = 1,64; IC95\% 1,29-2,10). Características ambientais associadas a velocidades mais altas e acidentes mais pesados podem aumentar a incidência deles. Conclusão: Constatamos que os centros comerciais ou turísticos com tráfego intenso são três áreas com alta densidade de acidentes. As autoridades locais podem usar essas descobertas para promover medidas de segurança no trânsito em áreas de alta incidência na cidade de León.

Palavras-chave: Acidentes de trânsito. Epidemiologia. Sistemas de Informação Geográfica. Nicarágua.

\section{INTRODUCTION}

Road traffic accidents (RTA) are a major public health problem, projected to severely increase in the coming decades. ${ }^{1,2}$ In 2015, it caused 1.2 million deaths globally, and by 2030 , projections say that as many as 2.2 million deaths will be attributed to this health problem. ${ }^{3}$ Furthermore, between 20 and 50 million people suffer some type of permanent physical disability due to accidents injuries. ${ }^{4}$ According to the World Health Organization (WHO), 90\% of years of life lost due to death or disability in low- and middle-income countries (LMIC) are attributable to traffic accidents, which becomes a major burden to their health systems. ${ }^{3,5}$

In LMIC, the incidence and importance of road traffic injuries has increased over the last decade. An article about traffic accidents and alcohol studied the number of injuries associated with accidents in some hospitals of Latin America and the Caribbean. Four countries of Central America were included in the study, and Nicaragua registered the highest number of injuries caused in RTA after Guatemala. ${ }^{6}$ Otherwise, the National Police Office alone reported annually the behavior of accidents in Nicaragua. For the last years, reports said RTA increased 31.6\% between 2010 and 2017 (23,797 to 43,912 accidents respectively), placing crashed as the leading cause of violent death (638 reports) in the country, over killings (114 reports) and murders (282 reports), quantifying its material damage at more than a half million dollars in 2017. A long time ago, some articles about injuries of accidents reported in a hospital of León Nicaragua were published. However, we cannot find new studies that explain what are happening with road traffic injuries in the last 10 years. ${ }^{7,8}$ One in every four deaths and two in every ten injuries caused by RTA happen to pedestrians, 
occurring primarily in cities with high population density. ${ }^{8}$ When some elements like good conditions of weather traffics signs and others are not present in streets, the likelihood of crashes occurring increases, even more in places with foot traffic. ${ }^{9}$ This suggests the need to study environmental characteristics that promote the occurrence of RTA, particularly in high-population areas like León, Nicaragua (2017 population: 208,792 ; density: $252 / \mathrm{km}^{2}$ ). ${ }^{8}$ Due to economic, touristic, and academic activity, the department of León is considered one of the most economically important departments in Nicaragua. ${ }^{10}$ National Police records indicate that next to Managua (capital city of the country, with $24 \%$ of deaths due to accidents) and Matagalpa (9.9\% of deaths due to accidents), León has registered a high number of death from crashes $(7.8 \%$, ranking third in mortality by RTA in the country), making it one of the most important cities to understand the patterns and predictors of RTA. ${ }^{8}$

Geographical information systems (GIS) allow the visualization of elements that are present in roads that may increase the likelihood of road traffic injuries. ${ }^{11-13}$ For example, areas of high commercial or touristic activity in which there is heavy foot traffic tend to have higher incidence of accidents. ${ }^{14-16}$ Likewise, studies show that areas near bus stops, colleges and universities, commercial centers, and hospitals increment the likelihood of crashes. ${ }^{17,18}$ The use of GIS to describe the environments in which RTA have occurred can facilitate the proper management of economic resources to mitigate its effects on health. ${ }^{19-22}$ The incorporation of GIS in studies based on hospital and police data have identified geographic areas at increased risk of negative health and safety outcomes, and can help local authorities to identify priority areas for preventive interventions. ${ }^{11}$

In Nicaragua, few studies have incorporated GIS to understand and effectively intervene on health issues in communities. The objective of this study was to identify environmental factors present in areas with high density of RTA in León City, Nicaragua, facilitating the understanding of the factors that contribute to accidents and permitting future interventions to reduce morbidity and mortality due to it.

\section{METHODS}

\section{DATA COLLECTION}

A cross-sectional study and spatial analysis in the city of León were conducted to examine the environmental conditions in the areas in which RTA occurred. Between January and June 2017, 738 records of accidents from National Police files were identified, in which 1,281 people were involved. Of these, 59 records $(8.0 \%)$ were missing basic data related to the people involved in the RTA, and 12 records (1.6\%) sites could not be located due to lack of documentation on the address of accident occurrence. We found complete information in 667 records (90.4\%), which were included in the study. Data were collected in two phases. In the first phase, the official records of each accident from the National Police Office of León were assessed to extract data about RTA, such as address and place of occurrence, 
time, date, cause of crashes, and characteristics of the people involved in them. The second phase consisted of georeferencing the sites where the traffic accident occurred and collecting environmental information of the site. We visited every site where an RTA occurred, and captured the latitude and longitude of the site using location sensors of mobile devices. Then, using an ad hoc questionnaire, we collected environmental data related to sites infrastructure, presence of trees in the street, among other information.

We employed a data collection instrument designed a priori to abstract data from each record found in police documents, including sociodemographic aspects of people involved in the RTA; cause of crashes as determined by the National Police Office; resulting health condition of the people involved (uninjured; injured if any people of official health service transferred anyone involved in the RTA to a hospital or clinic); type of vehicle involved; and the roles of the individuals involved in the RTA. We also used the instrument to collect environmental data at the site of crashes, including road conditions ("good" if no damage to the infrastructure was observed; "under repair/bad" if the road was under construction by the local government, or if the road was damaged and not under construction); place of occurrence ("highway" the Pan American Highway that crosses the periphery of the city; "street"; and "avenue"); trajectory of the road (straight, curved, on a hill); road material ("paved", including asphalt, cobblestone, hydraulic and concrete, and "dirt") presence of a bicycle lane on the street (yes/no); presence of trees obstructing road view (yes/no); presence of a stoplight (yes/ no); presence of street signs indicating traffic laws or potential hazards (yes/no); and presence of informal businesses in public walkways that obstruct foot traffic (yes/no). These environmental elements were then measured within a circumference of 20 meters from the site where the RTA occurred and were recorded in the data collection instruments at the time of site visit. The instrument was piloted with 30 records from December 2016. We identified and corrected weaknesses in the instrument that prevented high-quality abstraction of data from Police records, and recorded environmental data from traffic accident sites.

We created an electronic version of the data collection instrument with the Epicollect5 platform (Imperial College of London, United Kingdom: https: / / five.epicollect.net), and collected georeferenced data and environmental data of the RTA using a phone mobile device. The precision of coordinates from the mobile device was tested by comparing them to those obtained from the high-precision Garmin ${ }^{\circledR}$ Global Positioning System GPSMAP $64 \mathrm{~S}$. We found a difference of less than five meters when we observed the values between the devices.

\section{DATA ANALYSES}

We used frequencies and proportions to describe the characteristics of the people involved in RTA and their health condition following the accidents, as well as the environmental factors that were present at the time of crashes. For the identification of factors associated with the occurrence of accidents, we first created the dependent variable, by clustering all traffic 
accidents located within a 20 meters circumference. As a result, 285 geographical spaces where at least one accident occurred were identified, and we defined the geographical spaces as the unit of analysis for the regression model. Independent variables were the environmental factors collected during RTA site visits. Then, we specified a generalized linear model with a Poisson distribution and log link function. This model is used when the data come from counts of events that occur by chance with a certain frequency and can be modeled in terms of incidence rates that depend on certain explanatory variables. The model allows us to control various independent variables simultaneously. The adequacy and convergence of the model was assessed using the Akaike information criteria, the residual versus fitted plot, the q-q plot of the residuals, the linearity plot (square root of the residual deviance versus predicted values), and residuals versus predictor variables. We obtained the statistics associated with the model to assess the existence of influential values.

In bivariate analyses, we estimated the incidence rate ratio (IRR) and $95 \%$ confidence interval $(95 \% \mathrm{CI})$ between the dependent variable and each independent variable. The environmental variables that were associated with accidents with $\mathrm{p}<0.2$ were included in a multivariable model to estimate adjusted IRRs. All analyses were conducted using Stata 12 (StataCorp: College Station, Texas, USA).

We used ArcGIS v.10.2 (Esri: Redlands, CA, USA) software to complete the spatial analysis. All geographic coordinates of the traffic accident sites obtained by mobile devices were re-coded in Universal Transverse Mercator projection (UTM projection) with the GeoConverter 1.0 software (Center for Demographic and Health Research, National Autonomous University of Nicaragua, León), and then exported to ArcGIS to create a shapefile (.shp) with all the geographic coordinates. We used the World Geodetic System 1984 (WGS 84 ) projected coordinate system, in which Nicaragua is in the $16^{\text {th }}$ zone North based on its geographic coordinates. We used the kernel density estimator (KDE) to analyze places with a high density of health events like RTA. The KDE calculated the distribution of points in a city or country to know the behavior of health problems, and it helps us identify the areas with high, moderate, and low density of crashes. ${ }^{23,24}$ Using a base map layer for León City from OpenStreetMap (openstreetmap.org), which provides weekly updates of map layers reflecting new roads and developments, we loaded the geographic locations of each accident as points on a map. The size of the search radius representing areas of high, moderate, and low density of RTA was automatically calculated by ArcGIS based on the median distance of all geographic points from the mean center of all entered points.

\section{ETHICAL CONSIDERATIONS}

The protocol for this study was approved by the Ethics Committee for Biomedical Research of the School of Medical Sciences at the National Autonomous University of Nicaragua, León. We also received the approval from the Chief of the delegation of the National Police to access the database of RTA during the study period. 


\section{RESULTS}

\section{CHARACTERISTICS OF PEOPLE INVOLVED IN TRAFFIC ACCIDENTS}

Of the people involved in RTA, 90\% were men and half were adults aged between 25 and 40. All deaths occurred among men, including three men younger than 40 , who were traveling on motorcycles. One death occurred to a 65 -year-old foreigner man (Table 1).

The main causes of RTA in which injuries or dead occurred, as established by the National Police, were: overtaking (20.9\%), disregard for traffic signals (14.9\%), and improper turning (13.4\%), which together represent $49.2 \%$ of causes of all crashes (Table 1). Other registered causes $(38.8 \%)$ included driving in reverse, mechanical failure, failure to respect pedestrians and stop on crosswalks, and failure to maintain a safe distance between vehicles.

\section{ENVIRONMENTAL FACTORS}

RTAs were distributed in 285 distinct geographic spaces within 20 meters of the locations of them. The bivariate regression analysis showed that crashes occurred twice as frequently on the highway as compared to street $(\mathrm{IRR}=1.72,95 \% \mathrm{CI} 1.30-2.27)$. Paved roads were associated two times more with the incidence of RTA compared to dirt roads (IRR $=2.11,95 \% \mathrm{CI} 1.09-4.08$ ), and roads in good conditions were associated with a $50 \%$ increase in the incidence of accidents compared to roads under repair/bad (IRR - 1.49, 95\%CI 1.26-1.78). Roads with a bicycle lane increase the incidence of RTA compared to roads without bicycle lanes (IRR = 1.89, 95\%CI 1.52-2.34) (Table 2).

In multivariable analysis, main road or highway compared to a street road remained significantly associated with and increased incidence of RTA (IRR $=1.40,95 \% \mathrm{CI} 1.02-1.92$ ), and roads in good conditions have more crashes compared to those under repair/bad (IRR = $1.36,95 \%$ CI $1.13-1.63$ ) as did the presence of a bicycle lane (IRR $=1.64,95 \%$ CI $1.29-2.10$ ) (Table 2). In these variables, the association was attenuated for other factors.

\section{SPATIAL ANALYSIS}

The city main roads were the locations with the highest number of RTA. The distribution of accidents that resulted in injury or death occurred on the main roads connecting the center of León City to the main interurbans roads of the city. More crashes were registered in the Northern part of the city, at the city exits, and in the stretch of the Pan-American Highway that crosses the city (Figure 1).

We mapped areas of high, moderate, and low density of RTA in Figure 2. One big area of low-density, seven areas of medium density, and three areas of high-density were found. According to the density map, crashes were most highly concentrated in the city center, stretching towards the North of the city and towards the highway (Figure 2). 
Table 1. Characteristics of people involved in road traffic accidents and their resulting health status, January-June 2017, León, Nicaragua $(n=1,281)$.

\begin{tabular}{|c|c|c|c|c|}
\hline \multirow[b]{2}{*}{ Variable } & \multicolumn{3}{|c|}{ Health Status } & \multirow[b]{2}{*}{$\begin{array}{l}\text { Total } \\
\text { n (\%) }\end{array}$} \\
\hline & $\begin{array}{c}\text { Uninjured } \\
(n=1,196) \\
n(\%)\end{array}$ & $\begin{array}{c}\text { Injured } \\
(n=81) \\
n(\%)\end{array}$ & $\begin{array}{c}\text { Dead } \\
(n=4) \\
n(\%)\end{array}$ & \\
\hline \multicolumn{5}{|l|}{ Sex } \\
\hline Male & $1,076(89.9)$ & $65(80.2)$ & $4(100.0)$ & $1145(89.4)$ \\
\hline Female & $120(10.1)$ & $16(19.8)$ & - & $136(10.6)$ \\
\hline \multicolumn{5}{|l|}{ Age (years old) } \\
\hline $0-18$ & $8(0.7)$ & $10(12.3)$ & $1(25.0)$ & $19(1.5)$ \\
\hline $19-24$ & $177(14.8)$ & $17(21.0)$ & $1(25.0)$ & $195(15.2)$ \\
\hline $25-40$ & $574(48.0)$ & $43(53.1)$ & $1(25.0)$ & $618(48.2)$ \\
\hline $41-64$ & $398(33.3)$ & $10(12.3)$ & - & $408(31.9)$ \\
\hline 65 or more & $39(3.3)$ & $1(1.2)$ & $1(25.0)$ & $41(3.2)$ \\
\hline \multicolumn{5}{|l|}{ Nationality } \\
\hline Nicaraguan & 1,179 (98.9) & $81(100.0)$ & $3(75.0)$ & $1,263(98.6)$ \\
\hline Foreigner & $17(1.1)$ & - & $1(25.0)$ & $18(1.4)$ \\
\hline \multicolumn{5}{|l|}{ Role in the RTA } \\
\hline Driver & 1,192 (99.7) & $59(71.6)$ & $2(50.0)$ & $1,253(97.8)$ \\
\hline Passenger & $3(0.2)$ & $14(17.4)$ & $1(25.0)$ & $18(1.4)$ \\
\hline Pedestrian & $1(0.1)$ & $8(9.9)$ & $1(25.0)$ & $10(0.8)$ \\
\hline \multicolumn{5}{|l|}{ Type of vehicle ${ }^{a}$} \\
\hline Cars & $610(51.0)$ & $37(31.3)$ & $1(25.0)$ & $648(49.6)$ \\
\hline Motorcycles & $293(24.4)$ & $59(50.0)$ & $3(75.0)$ & $348(26.5)$ \\
\hline Public transportation & $139(11.6)$ & $13(11.0)$ & - & $152(11.6)$ \\
\hline Heavy transportation & $114(9.5)$ & $4(3.3)$ & - & $118(9.0)$ \\
\hline Other & $32(2.6)$ & $5(4.2)$ & - & $37(2.8)$ \\
\hline \multicolumn{5}{|l|}{ Causes of RTA ${ }^{b}$} \\
\hline Overtaking ${ }^{c}$ & $91(15.1)$ & \multicolumn{2}{|c|}{$14(20.9)$} & $105(15.7)$ \\
\hline Disregard for traffic signals & $84(13.9)$ & \multicolumn{2}{|c|}{$10(14.9)$} & $94(14.1)$ \\
\hline Wrong-way driving & $79(13.1)$ & \multicolumn{2}{|c|}{-} & $79(11.8)$ \\
\hline Unsafe distance & $207(34.4)$ & \multicolumn{2}{|c|}{$8(11.9)$} & $215(32.12)$ \\
\hline Improper turn & $60(9.9)$ & \multicolumn{2}{|c|}{$9(13.4)$} & $69(10.3)$ \\
\hline Others ${ }^{d}$ & $80(13.3)$ & \multicolumn{2}{|c|}{$26(38.8)$} & $106(15.8)$ \\
\hline
\end{tabular}

RTA: road traffic accident; athe total number of vehicles involved in road traffic accidents exceeds the number of crashes, as multiple vehicles may have been involved in a single accident: uninjured $(n=1,188)$, injured $(n=118)$,

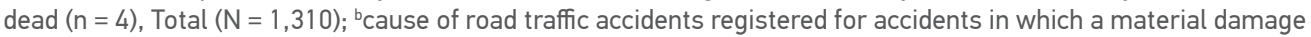
(uninjured) or human damage (injured or death) occurred; ' when a vehicle invades the lane due to a fixed or moving obstacle in front of it; 'dother causes of crashes include driving in reverse, mechanical failure, failure to yield rightof-way to pedestrians. 
Table 2. Environmental factors of geographic spaces and associations with number of road traffic accidents, January-June 2017, León, Nicaragua ( $N=285$ ).

\begin{tabular}{|c|c|c|c|c|c|}
\hline Variable & $\mathrm{n}$ & $\begin{array}{c}\text { Crude IRR } \\
(95 \% \mathrm{Cl})\end{array}$ & $\mathrm{p}$-value & $\begin{array}{l}\text { Adjusted IRR* } \\
(95 \% \mathrm{Cl})\end{array}$ & $\mathrm{p}$-value \\
\hline \multicolumn{6}{|l|}{ Place of occurrence } \\
\hline Street & 143 & Ref. & & Ref. & \\
\hline Avenue & 127 & $1.01(0.86-1.18)$ & 0.866 & $1.02(0.87-1.20)$ & 0.770 \\
\hline Highway & 15 & $1.72(1.30-2.27)$ & $<0.001$ & $1.40(1.02-1.92)$ & 0.034 \\
\hline \multicolumn{6}{|l|}{ Road material } \\
\hline Paved & 277 & $2.11(1.09-4.08)$ & \multirow{2}{*}{0.026} & $1.49(0.76-2.95)$ & \multirow{2}{*}{0.241} \\
\hline Dirt & 8 & Ref. & & Ref. & \\
\hline \multicolumn{6}{|l|}{ Condition of the road } \\
\hline Under repair/bad & 100 & Ref. & \multirow{2}{*}{$<0.001$} & Ref. & \multirow{2}{*}{0.001} \\
\hline Good & 185 & $1.49(1.26-1.78)$ & & $1.36(1.13-1.63)$ & \\
\hline \multicolumn{6}{|c|}{ Presence of bicycle lane } \\
\hline Yes & 24 & $1.89(1.52-2.34)$ & \multirow{2}{*}{$<0.001$} & $1.64(1.29-2.10)$ & \multirow{2}{*}{$<0.001$} \\
\hline No & 261 & Ref. & & Ref. & \\
\hline
\end{tabular}

IRR: incidence rate ratio; 95\% Cl: 95\% confidence interval; Ref.: reference; *each variable adjusted for all other variables in the table.

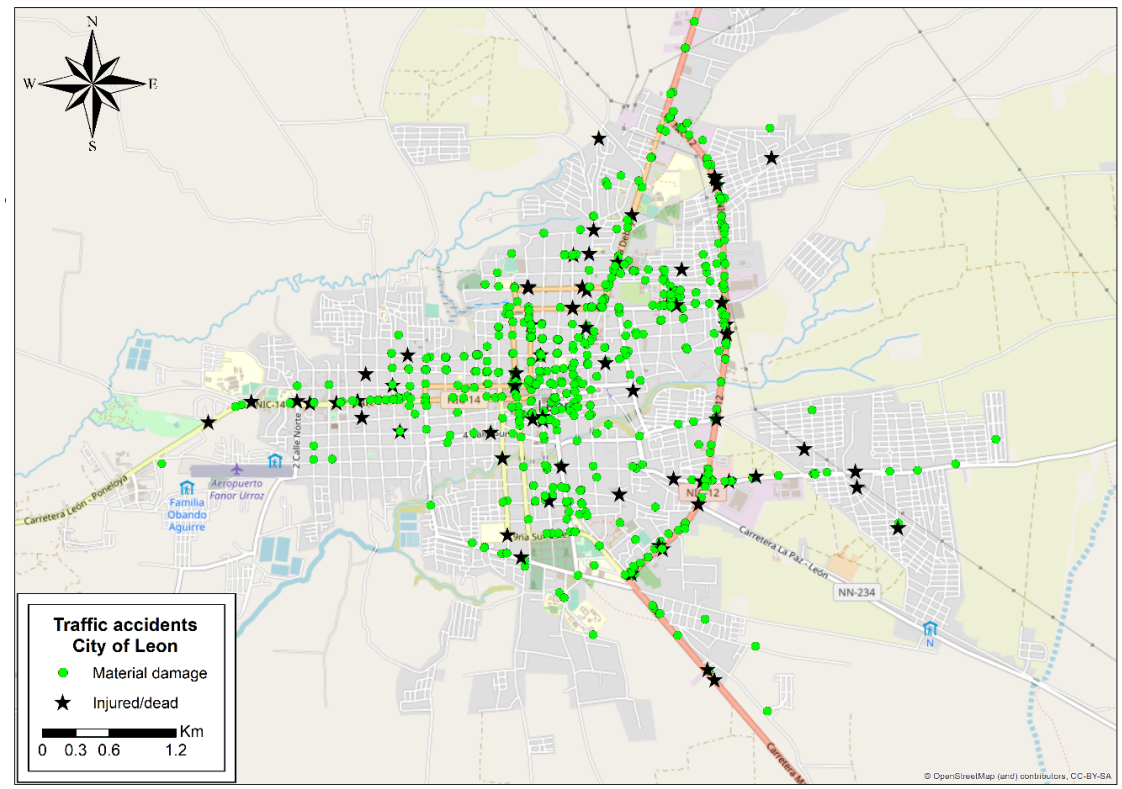

Figure 1. Distribution of road traffic accidents by severity of crash, January-June 2017, León, Nicaragua. The green points indicate crashes that did not result in injuries but resulted in material damage. The black stars indicate accidents that resulted in injury or death. 


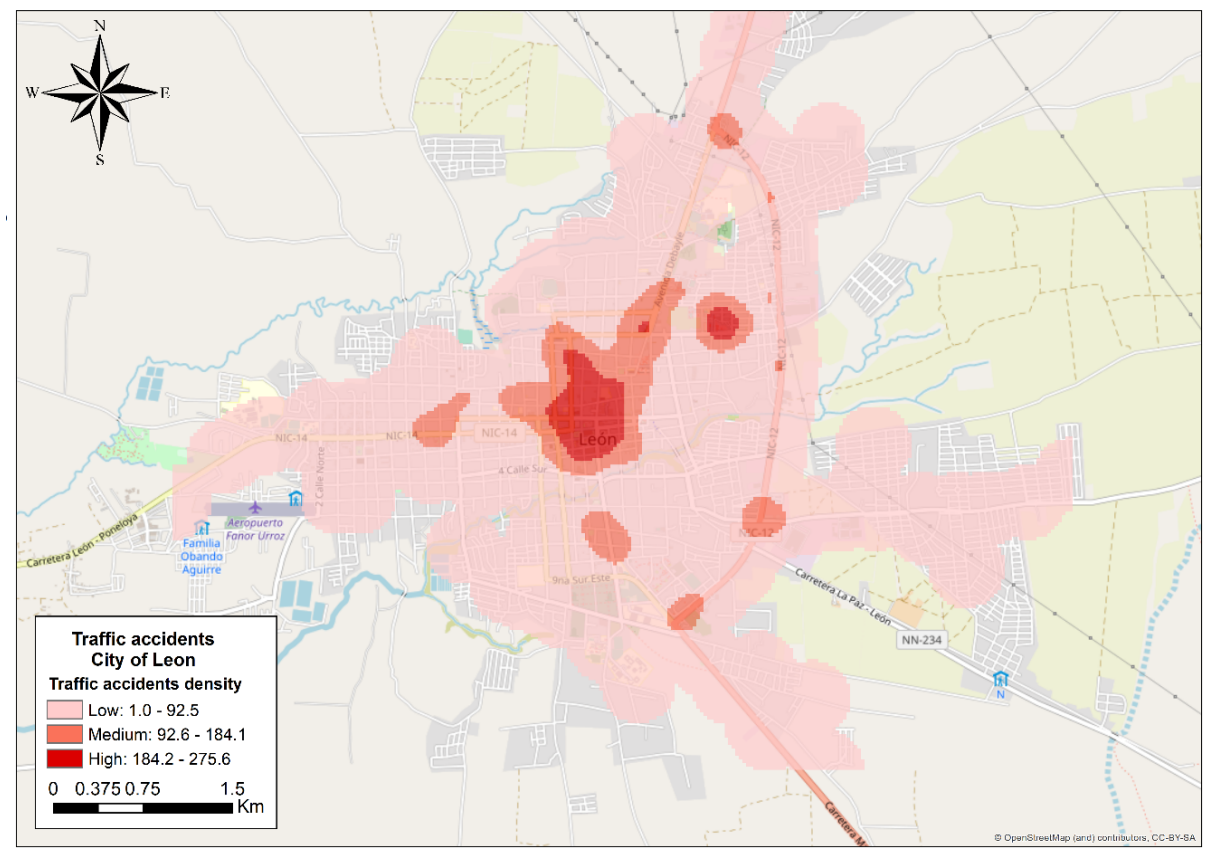

Figure 2. Kernel density of road traffic accidents in León, Nicaragua, January-June 2017. Three areas of high density (between 184 to 275 crashes) were identified in León City, near the entrance of the highway, and the bus station with high commercial, touristic and educational activities.

\section{DISCUSSION}

In an analysis of environmental and spatial correlates of RTA in León, Nicaragua, the location of the accidents on high-traffic roads, the presence of bicycle lanes, good conditions of the road, paved roads, and bicycle lanes were associated with an increased incidence of crashes. We identified three zones with high density of RTA, which were in areas with the heaviest commercial, touristic, and educational activities in the city. Such data can be used to assess needs for road safety interventions to prevent injury and death due to accidents.

It has been documented that human error influenced by environmental factors and deficiencies in road maintenance are associated with involvement in a RTA. ${ }^{14}$ The presence of intersections, trees that obstruct vision while driving or walking, and pedestrian space occupied by informal businesses can increase the risk of crashes. ${ }^{15,16,25}$ In this study, a greater number of accidents occurred on asphalt roads that were in good conditions and on roads that contained bicycle lanes. This is in line with previous studies that showed association of adverse infrastructure conditions, such as road surface conditions, street type and road width, lighting as well as location type with higher odds to RTA. ${ }^{26}$ This finding can be explained because geometry limits the driver's vision and makes it difficult to control the vehicle at crash time with subsequent increase in fatal crashes risk. ${ }^{27}$ 
Good road conditions and pavement are conducive to a higher density of vehicular traffic $^{26}$ and exceeding speed limits, ${ }^{27}$ which put others at risk of being injured due to an RTA. ${ }^{28}$ These conditions were present in the zones we identified having the highest density of accidents. Implementing regulatory measures to control traffic in essential, including adequate traffic signaling in streets with greater presence of vehicles and pedestrians, particularly young and elderly pedestrians who are most vulnerable to injury or death due to RTA. ${ }^{9}$ Some variables like road use, traffic density in streets and the foot traffic frequency on a daily basis are fundamental to control the effect of this study in the results about distribution and severity of crashes in León City. Those data are not found in Nicaragua.

With respect to the zones with high density of road accidents, we identified the largest zone in the city's historic center. The frequency of people conducting commercial activities and the proximity of intersections are key factors that can increase the risk of accidents. ${ }^{12,17}$ The historic center and the bus terminal comprise the city's financial district, in which commercial activity and foot traffic are present daily. This sector comprehends five of the primary markets in the city, and the main private schools and university campuses which accommodate thousands of students every day. These locations, in agreement with studies from other countries, lead to high concentrations of people and pedestrian traffic during large parts of the day and other factors that are present in these areas, which can lead to RTA..$^{29-32}$ In this study, we found a high increase of crashes in places with bicycle lanes. This behavior is similar to that found in a study in Australia, in which road accidents were 5.3 times more frequent in streets with bicycles lanes. ${ }^{33}$ Besides that, the result indicated that bicycles lanes were more beneficial where traffic lanes are narrower. However, our study cannot establish an analysis controlled between risk to bicycle lanes and other variables like the size of the lane, the speed limit of cars in the street, and exclusive bicycle lanes.

Considering the high density of RTA that we observed in the stretch of the Pan-American Highway crossing the city, the high volume of vehicular traffic, including cargo vehicles like trucks and vans, can influence the rates of crashes. ${ }^{34}$ The Sustainable Development Goals want to mobilize financing and support to the governments with specific actions to reduce mortality and injuries to RTA and implementation of measures to guarantee road safety before 2030 leaving no one behind. ${ }^{35}$ In countries where these strategies are being implemented, despite using different strategies depending on the particular characteristics of each country, the rates of accidents are decreasing. ${ }^{19}$ Our spatial analysis using GIS allowed us to visualize the occurrence of road accidents in a simple yet impactful way, serving as a useful tool to aid in developing urban and health policies. ${ }^{15,36-39}$ The occurrence of crashes in areas of high density could be prevented by implementing improved road signaling, traffic management, and repair of damaged roads. ${ }^{19}$ Despite limited resources, LMIC like Nicaragua's should consider including effective administration of urban population growth and public transportation in public policies, prioritizing use of alternate routes during periods of heavy vehicular and pedestrian traffic.

One of the limitations of this study concerns the temporality of events, given that the measurement of environmental variables occurred sometime after the RTA. However, 
data allowed us to identify potential environmental hazards on which the local government can intervene to prevent crashes in the future. Nine percent of the records of accidents were incomplete and could not be geo-referenced, which precluded spatial analysis of all then. This could induce bias if these road accidents with missing geographical data tended to be concentrated in a location. We were unable to consider the density of crashes with respect to the number of vehicles on the road or people living in the surrounding neighborhoods due to lack of municipal data of this type. Furthermore, the quality of information collected from police records must be considered, as the data is based on subjective observations made by officers who were present at the time of the RTA, and in the records of health conditions of people involved in accidents. However, the National Police maintains the records of all accidents reported by the population, and officers are trained in traffic law and appropriate documentation of the circumstances. Finally, the National Police Office should be generating constant reports about the status of all road accidents and integrating other key actors like the Ministry of Health and city halls to have complete information about it.

In conclusion, we found that good road conditions and the use of highways or main roads were associated with higher incidence of RTA. We identified three zones with a high density of crashes where commercial, touristic, and educational activities are present. These results should be considered by institutions involved in the administration of road conditions and road safety to build strategies that promote the development of safe urban spaces with low occurrence of injury or death due to RTA.

\section{ACKNOWLEDGMENTS}

We thank the police of León for their collaboration in allowing us to access the records of traffic accidents. We also thank William Ugarte, Braulio Espinoza, Andrés Herrera, and the staff of the CIDS for their ideas and contributions to this work. We thank Katherine Saldaña, Carolina Flores, Modesto Herrera, and José Levi Salinas for their work in data collection. Finally, we thank Nadja Vielot for translating this manuscript. Thanks to all.

\section{REFERENCES}

1. Global Burden of Disease Study 2017. Global, regional, and national incidence, prevalence, and years lived with disability for 354 Diseases and Injuries for 195 countries and territories, 1990-2017: A systematic analysis for the Global Burden of Disease Study 2017. Lancet 2018; 392(10159): 1789-858. https:// doi.org/10.1016/ S0140-6736(18)32279-7
2. Foreman KJ, Marquez N, Dolgert A, Fukutaki K, Fullman N, McGaughey M, et al. Forecasting life expectancy, years of life lost, and all-cause and causespecific mortality for 250 causes of death: reference and alternative scenarios for 2016-40 for 195 countries and territories. Lancet 2018; 392(10159): 2052-90. https: / doi.org/10.1016/S0140-6736(18)31694-5 
3. World Health Organization (WHO). Global status report on road safety 2018 [Internet]. WHO; 2019 [cited 2019 Oct 8]. Available from: https:/ /www.who.int/ violence_injury_prevention/road_safety_status/2018/en/

4. World Health Organization (WHO). Global status report on road safety 2015 [Internet]. WHO; 2018 [cited 2019 Oct 3]. Available from: https:/ / apps.who. int/iris/bitstream/handle/10665/277370/WHO-

NMH-NVI-18.20-eng.pdf?ua $=1$

5. Nantulya V, Reich MR. The neglected epidemic: road traffic injuries in developing countries The Harvard community has made this article openly available. The neglected epidemic: road traffic injuries in developing countries. BMJ [Internet] 2012 [cited 2019 Oct 8]; 324(7346): 1139-41. Available from: https: / www.ncbi. nlm.nih.gov/pmc/articles/PMC1123095/https:/ / doi. org/10.1136\%2Fbmj.324.7346.1139

6. Borges G, Monteiro M, Cherpitel CJ, Orozco R, Ye Y, Poznyak V, et al. Alcohol and Road Traffic Injuries in Latin America and the Caribbean: A Case-Crossover Study. Alcohol Clin Exp Res 2017; 41(10): 1731-7. https: / / doi.org/10.1111/acer.13467

7. Instituto Nacional de Información de Desarrollo (INIDE). Anuario Estadístico 2010 [Internet]. Instituto Nacional de Información de Desarrollo; 2010 [cited 2019 Oct 7]. Available from: https://www.inide. gob.ni/docs/bibliovirtual/Anuarios / ANUARIO10/ Anuario2010.pdf

8. Instituto Nacional de Información de Desarrollo (INIDE). Anuario Estadístico 2017 [Internet]. Nicaragua: Instituto Nacional de Información de Desarrollo; 2019. Available from: http: / / www.inide.gob.ni/Anuarios/ Anuario2017.pdf

9. Malin F, Norros I, Innamaa S. Accident risk of road and weather conditions on different road types. Accid Anal Prev 2019; 122: 181-8. https:// doi.org/10.1016/j.aap.2018.10.014

10. Instituto Nacional de Desarrollo (INIDE). Censo Económico Urbano CEU 2010 León, resultados departamento de León [Internet]. Nicaragua: Instituto Nacional de Información de Desarrollo; 2012 [cited on 2020 Oct 21]. 71 p. Available from: https: / / www. inide.gob.ni/docs/CensoEconomico/InformesDept/ ceu2010Leon/informeLeon.pdf

11. Ahmadi M, Valinejadi A, Goodarzi A, Safari A, Hemmat M, Askari Majdabadi H, et al. Geographic Information System (GIS) capabilities in traffic accident information management: a qualitative approach. Electron Physician 2017; 9(6): 4533-40. https:// doi.org/10.19082/ 4533

12. Huang Y, Wang X, Patton D. Examining spatial relationships between crashes and the built environment: A geographically weighted regression approach. J Transp Geogr 2018; 69: 221-33. https:/ / doi.org/10.1016/j.jtrangeo.2018.04.027
13. Kang Y, Cho N, Son S. Spatiotemporal characteristics of elderly population's traffic accidents in Seoul using space-time cube and space-time kernel density estimation. PLoS One 2018; 13(5): e0196845. https: / / doi.org/10.1371/journal.pone.0196845

14. Najar FGDQ, Pérez MGG, Lara YA. Determinación de los componentes entrópicos de la accidentalidad: el trinomio vehículo/usuario/camino en la metrópoli de Guadalajara, México. Rev Tecnura 2018; 22(55): 51-65. http:/ / doi.org/10.14483/22487638.13245

15. Hernández-Vásquez A, Azañedo D, Bendezú-Quispe G, Pacheco-Mendoza J, Chaparro RM. Sistemas de información geográfica: aplicación práctica para el estudio de atropellos en el Cercado de Lima, Perú. Rev Peru Med Exp Salud Publica 2016; 33(4): 725-31. http:/ / doi.org/10.17843/rpmesp.2016.334.2558

16. Yalcin G, Duzgun HS. Spatial analysis of two-wheeled vehicles traffic crashes: Osmaniye in Turkey. KSCE J Civ Eng 2015; 19(7): 2225-32. https: / / doi.org/10.1007/s12205-015-0661-0

17. Hernández-Hernández V, León LDH-D. La Relación entre la centralidad urbana y los atropellamientos en la ciudad de Juárez, México. Hacia Promoc Salud 2014; 19(2): 81-94.

18. Bonfim CV do, Silva AGS da, Araújo WM de, Alencar C, Furtado, Alencar BM. Análisis de la distribución espacial de los accidentes de transporte terrestre atendidos por el Servicio Móvil de Urgencia (SAMU192), en un municipio de la región nordeste de Brasil. Salud Colect [Internet]. 2018 [cited on 2019 Sept 11]; 14(1): 65-75. Available from: http:// revistas.unla.edu. ar/saludcolectiva/article/view/1211/pdf. https: / / doi.org/10.18294/sc.2018.1211

19. Ma F, Li X, Sun Q, Liu F, Wang W, Bai L. Regional differences and spatial aggregation of sustainable transport efficiency: A case study of China. Sustain 2018; 10(7): 2399. https: / / doi.org/10.3390/su10072399

20. Erdogan S. Explorative spatial analysis of traffic accident statistics and road mortality among the provinces of Turkey. J Safety Res [Internet]. 2009 [cited 2019 Oct 3]; 40(5): 341-51. Available from: http://www. ncbi.nlm.nih.gov/pubmed/19932314. https: / doi. org/10.1016/j.jsr.2009.07.006

21. Soltani A, Askari S. Exploring spatial autocorrelation of traffic crashes based on severity. Injury 2017; 48(3): 637-47. https:// doi.org/10.1016/j.injury.2017.01.032

22. Gundogdu IB. Applying linear analysis methods to GIS-supported procedures for preventing traffic accidents: Case study of Konya. Saf Sci 2010; 48(6): 763-9. https: / / doi.org/10.1016/j.ssci.2010.02.016

23. Kang Y, Cho N, Son S. Spatiotemporal characteristics of elderly population's traffic accidents in Seoul using space-time cube and space-time kernel density estimation. PLoS One 2018; 13(5): e0196845. https: / / doi.org/10.1371/journal.pone.0196845 
24. Fotheringham AS, Brunsdon C, Charlton M. Quantitative geography: perspectives on spatial data analysis. Londres: Sage, 2000.

25. Prieto Curiel R, González Ramírez H, Bishop SR. A novel rare event approach to measure the randomness and concentration of road accidents. PLoS One [Internet] 2018 [cited 2019 Aug 23]; 13(8): e0201890. Available from: https://doi.org/10.1371/journal. pone.0201890.g001. https:// doi.org/10.1371/journal. pone. 0201890

26. Kashani AT, Shariat-Mohaymany A, Ranjbari A. Analysis of factors associated with traffic injury severity on rural roads in Iran. J Inj Violence Res 2012; 4(1): 36-41. https: / / doi.org/10.5249\%2Fjivr.v4i1.67

27. Lankarani KB, Heydari ST, Aghabeigi MR, Moafian G, Hoseinzadeh A, Vossoughi M. The impact of environmental factors on traffic accidents in Iran. J Inj Violence Res 2014; 6(2): 64-71. https: / / doi.org/ 10.5249/ jivr.v6i2.318

28. Moreira JS, León CC, Zambrano GR, Joel Julio CM. Parámetros que influyen en el congestionamiento vehicular. Int J Innov Appl Stud 2018; 24(4): 1440-55.

29. Carro-Pérez EH, Ampudia-Rueda A. Conductas de riesgo al conducir un automóvil en zonas urbanas del sur de Tamaulipas y la Ciudad de México. Cienc UAT 2019; 13(2): 100-12. https:// doi.org/10.29059/ cienciauat.v13i2.988

30. Vanerio P, Trostchansky J, Machado F, Barrios G. Impacto de la ley uruguaya de seguridad vial en la mortalidad por siniestros de tránsito. Rev Medica del Uruguay 2018; 34(3): 45-61. http: / / doi.org/10.29193/ rmu.34.3.4

31. Narváez YV, Parra Sierra V, Peña Cárdenas F, Ruíz Ramos L, Zamorano González B, Vargas Martínez JI, et al. Road risk behaviors: Pedestrian experiences. Traffic Inj Prev 2019; 20(3): 303-7. https: / / doi.org/ 1 $0.1080 / 15389588.2019 .1573318$

32. Gallardo VA, Muñóz MP. El peatón en la vía pública [Social Communication Degree] [Internet]. Santiago, Chile: Universidad Finis Terrae; 2019 [cited on 2020 June 21]. 47 p. Available from: http:/ / repositorio.uft.cl/xmlui/ handle $/ 20.500 .12254 / 1507$ ? show $=$ full
33. Herrero-Fernández D. Desarrollo de un cuestionario breve para la medición del comportamiento arriesgado en peatones adolescentes. Rev Colomb Psicol [Internet] 2015 [cited on 2019 Sept 30]; 24(2): 271-84. Available from: http://www.scielo.org.co/pdf/rcps/v24n2/v24n2a03. pdf. http: / / doi.org/10.15446/rcp.v24n2.43567

34. Koh PP, Wong YD, Chandrasekar P. Safety evaluation of pedestrian behaviour and violations at signalised pedestrian crossings. Saf Sci 2014; 70: 143-52. https: / / doi.org/10.1016/j.ssci.2014.05.010

35. Morrison CN, Thompson J, Kondo MC, Beck B. On-road bicycle lane types, roadway characteristics, and risks for bicycle crashes. Accid Anal Prev 2019; 123: 123-31. https:/ / doi.org/10.1016/j.aap.2018.11.017

36. Blazquez CA, Picarte B, Calderón JF, Losada F. Spatial autocorrelation analysis of cargo trucks on highway crashes in Chile. Accid Anal Prev 2018; 120: 195-210. https:// doi.org/10.1016/j.aap.2018.08.022

37. Naciones Unidas. Infraestructura - Desarrollo Sostenible [Internet]. Naciones Unidas [cited on 2019 Sep 11]. Available from: https://www.un.org/ sustainabledevelopment/es/infrastructure/

38. Jia R, Khadka A, Kim I. Traffic crash analysis with point-of-interest spatial clustering [Internet]. Accid Anal Prev 2018 [cited 2019 Aug 23]; 121: 223-30. Available from: https: / / doi.org/10.1016/j.aap.2018.09.018

39. Loyola E, Castillo-Salgado C, Nájera-Aguilar P, Vidaurre M, Mujica O, Martínez-Piedra R. Los sistemas de información geográfica como herramienta para monitorear las desigualdades de salud. Rev Panam Salud Publica 2002; 12(6): 415-28.

Received on: 02/05/2020

Revised on: 08/01/2020

Accepted on: 08/04/2020

Authors' contributions: Christian Toval-Ruiz: conceptualization, data curation, formal analysis, methodology, writing — original draft, writing review \& editing. Carlos Rojas-Roque: methodology, formal analysis, writing — review \& editing. Akram Hernádez-Vásquez: conceptualization, methodology, supervision, writing - review \& editing 